\title{
Bioclimatic design as a large city urban structure reorganization factor
}

\author{
Maria Zharkova ${ }^{1}$, Oksana Paramonova $^{1}$, and Natalia Yudina $^{1 *}$ \\ ${ }^{1}$ Don State Technical University, 1, Gagarin Sq., 344003, Rostov-on-Don, Russia
}

\begin{abstract}
The modern landscape of a large city is a complex, dynamically changing environment with a constant influence of environmental, social and economic factors. The gradual historical development of the territory and the change in urban processes led to the formation of a city containing mixed-type areas, i.e. border territories and separate zones - industrial, residential, intermediate. In Russia, the improvement of coastal zones in large cities has become an urgent task when adjusting master plans for the development of territories [1-5]. The main component of such projects is the development of a concept for the renovation of coastal zones into generally accessible natural and recreational recreation areas based on water bodies within the urban planning. The creation of recreations, recreation areas, the formation of a system of pedestrian communications, the opening of residential complexes to the water, the integration of water into public urban spaces [2-6]. A comprehensive analysis of theoretical studies and design experience made it possible to highlight the properties of water used in architecture and urban planning. Thus, the development of a promising bioclimatic model of urban settlements of the third millennium will be based on ecological design, which includes part of the processes of the circulation of substances and energy, as well as harmony in the environment [6-9].
\end{abstract}

\section{Introduction}

It is known that the urbanized landscape of the city requires an expansion of the scale and territories while maintaining the multifunctionality of spaces. The hybrid nature of landscape urbanism is based on the interaction of landscape architecture and urban planning, which use the landscape as the primary basis for the formation of the city [2-6].

Landscape architect James Corner proposed methods for the successful interaction of environmental objects and anthropogenic pressures in the design of coastal urban areas:

1) long-term design method as optimization of the landscape system with deep analytics and improving the quality of organic and technological indicators;

2) a method of forming connections through the creation of large-scale systems of urban infrastructure and flexible networks of interaction of environmental components;

3) social impact method [6-10].

\footnotetext{
* Corresponding author: udi-natasha@yandex.ru
} 
Currently, the classification features of water components and structures in the formation of the urban environment require additional scientific substantiation. The use of the physical and morphological properties of water, the active introduction of water into the structure of urban spaces and buildings is often intuitive. Identified by V.A. Nefedov, Polyakova A.B., the forms of interaction between architecture and water (contact with a water mirror, water shell, water fragment of the interior) create the prerequisites for deepening and expanding the topic in this area $[11,12]$.

Currently, the classification features of water components and structures in the formation of the urban environment require additional scientific substantiation. The use of the physical and morphological properties of water, the active introduction of water into the structure of urban spaces and buildings is often intuitive. Identified by V.A. Nefedov, Polyakova A.B., the forms of interaction between architecture and water (contact with a water mirror, water shell, water fragment of the interior) create the prerequisites for deepening and expanding the topic in this area.

The following types of architectural and urban planning objects related to water are distinguished: drive object, surface object, underwater object, floating object, waterstructured object, water-containing object, water-green object.

Planning structures of cities on waterways acquire an orbital character. First, a near orbit appears around the central core, and then, sequentially, distant orbits are formed. The trend of aquacentric development can be seen in the example of Kazan, Moscow, Volgograd, Tbilisi, San Francisco, London, Paris and many others [3, 6, 7, 12, 13].

The main water bodies flowing through the territory of the city are rivers. A general analysis of the territories adjacent to the riverbed within the city boundaries showed the need to divide the study area into sections, taking into account the temporal formation, urban planning situation, and the degree of transformation. In this case, all objects bordering the river are considered, which are sources of impact on the water body under consideration. When conducting a study of the adjacent territory, it is also necessary to take into account the flora and fauna of the area.

The assessment of the planning structure of cities on waterways, taking into account the study of the ecological state of a water body, was carried out by the authors on the example of the Temernik river, flowing through the territory of the city with a population of one million Rostov-on-Don [3, 6, 12, 13].

Within the framework of the administrative zoning of the territory of Rostov-on-Don and taking into account the maximum attractiveness of the landscape for the development of the park zone, the authors chose the territory shown in Fig. 1.

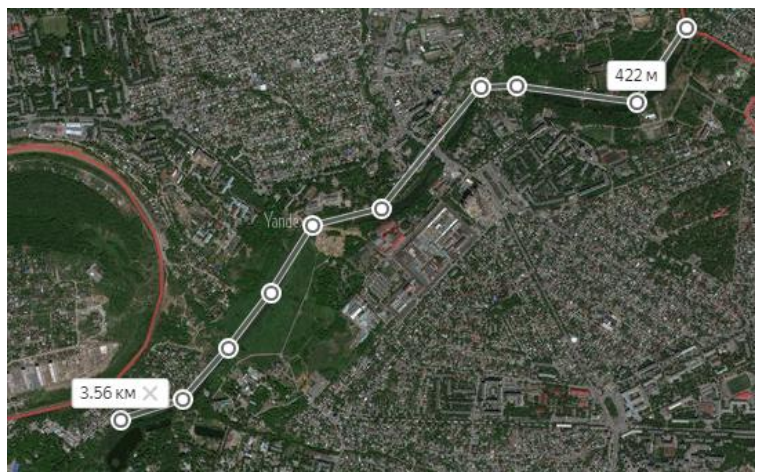

Fig. 1. Study area of the Temernik river within the boundaries of the region of Rostov-on-Don.

Within the coastal protective strip of the river. Temernik, at the survey site, there are private households of citizens, summer cottages, forest plantations, marshlands, a 
sanatorium zone, and a coastal strip of public access. The results of studies of the technogenic load from sources of pollution of the river are given on the example of one of the investigated sections of the river Temernik, flowing through the territory of Rostov-onDon (Fig. 2 and 3, Table 1).

The length of the surveyed section of the river Temernik was $1.4 \mathrm{~km}$

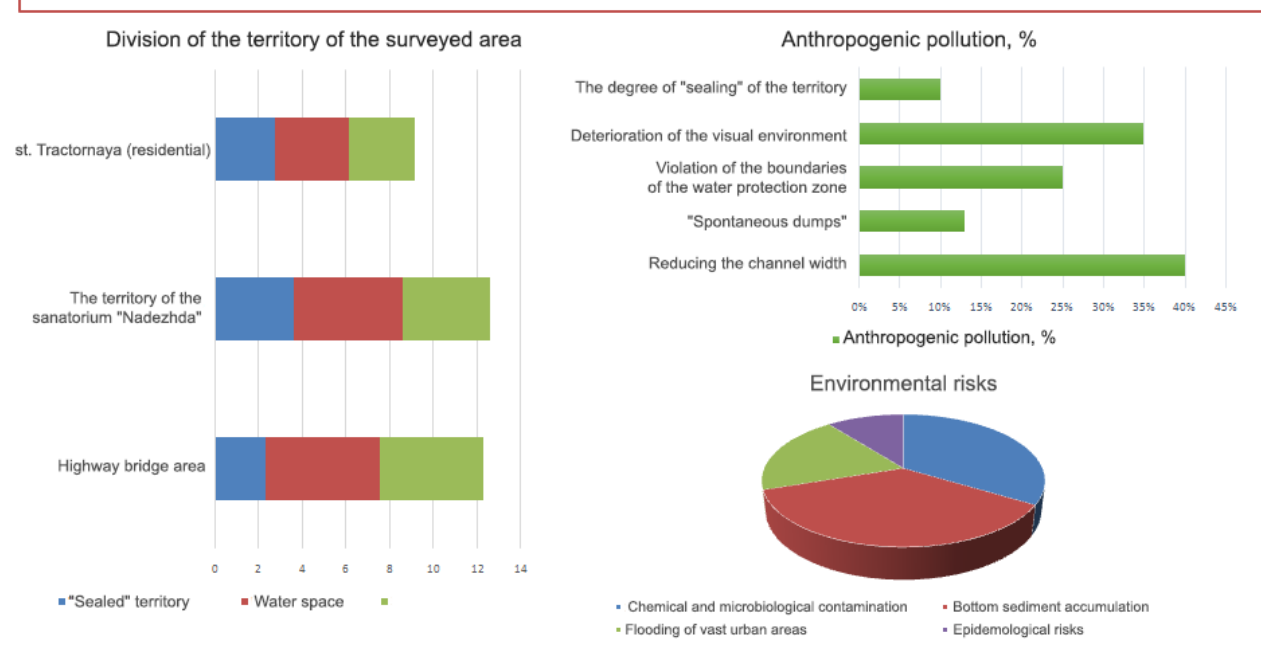

Fig. 2. Analysis of technogenic load on the research site №1.



Fig. 3. Points of monitoring of environmental objects at the study site №1.

Scheme of pollutant flows for the territory of the river Temernik is presented in Table 1.

Table 1. Anthropogenic impacts on the territory of the water protection zone of the river Temernik $[14,15]$.

\begin{tabular}{|c|c|}
\hline Types of impacts & List of sources of exposure \\
\hline areal & $\begin{array}{c}\text { functional zones: Res (residential area) }-1, \text { Ind (industrial area) }-1, \text { Rec } \\
\text { (recreational area) }-1\end{array}$ \\
\hline point & storm sewer discharge points \\
\hline linear & two railway bridges crossing the riverbed \\
\hline static & residential one-storey building \\
\hline dynamic & automobile transport \\
\hline long-term & anthropogenic load \\
\hline near-surface & upper layers of water masses \\
\hline
\end{tabular}


The analysis of the technogenic load made it possible to rank the processes leading to the pollution of the water body under consideration. Ranking of processes affecting the pollution of surface waters of the river Temernik is presented in Table 2.

Table 2. Ranking of processes affecting the pollution of surface waters of the river. Temernik.

\begin{tabular}{|c|c|c|c|}
\hline Contact media & Process groups & Process name & $\begin{array}{c}\text { Type of anthropogenic } \\
\text { pollution }\end{array}$ \\
\hline \multirow{9}{*}{$\begin{array}{l}\text { Atmosphere - } \\
\text { Hydrosphere }\end{array}$} & \multirow{4}{*}{ Chemical } & Adsorption & \\
\hline & & Sedimentation & \\
\hline & & Dissolution & \multirow{7}{*}{$\begin{array}{l}\text { Microbiological, eutrophication } \\
\text { of the water system }\end{array}$} \\
\hline & & Oxidation & \\
\hline & \multirow{3}{*}{ Biochemical } & Gassing & \\
\hline & & $\begin{array}{c}\text { Accumulation of } \\
\text { precipitation }\end{array}$ & \\
\hline & & Mixing of water masses & \\
\hline & \multirow{2}{*}{ Biological } & Photosynthesis & \\
\hline & & Respiration & \\
\hline \multirow{2}{*}{$\begin{array}{l}\text { Pedosphere - } \\
\text { Hydrosphere }\end{array}$} & \multirow{2}{*}{ Physical } & Mixing & \multirow{2}{*}{ Physical, mechanical } \\
\hline & & Solids units transport & \\
\hline
\end{tabular}

Detailed study of the processes of surface water pollution made it possible to identify the polluting components of the river Temernik, which are shown in Table 3.

Table 3. Polluting components of the Temernik river $[14,15]$.

\begin{tabular}{|c|c|}
\hline The component being defined & $\begin{array}{c}\text { The multiplicity of exceeding the MPC by } \\
\text { sites }\end{array}$ \\
\hline Sulfate ion & 3,29 \\
\hline Ammonium ion & 3,63 \\
\hline Nitrate ion & 1,78 \\
\hline COD (Chemical Oxygen Demand) & 1,78 \\
\hline BOD (Biochemical Oxygen Demand) & 1,17 \\
\hline Cadmium & 1,0 \\
\hline
\end{tabular}

Wastewater from enterprises and organizations, discharged directly into the reservoir through streams and gullies, also have an additional negative impact on the ecological state of the Temernik river.

\section{Materials and methods}

When obtaining primary information on the object, reconnaissance, morphometric, cartographic, and computational methods were used. To generalize the results obtained, we used methodological approaches based on the basic provisions of systems analysis and the theory of systems modeling. 


\section{Results}

The environmental assessment of the water body (by the example of the Temernik River) of the environment, carried out by the authors, included the following main stages of research:

1. Study of the process of entering pollutants into the bed of the Temernik river.

The seasonal water balance of the small Temernik River consists of the inflow, discharge, and accumulation (change in stock) of water, taking into account atmospheric precipitation, moisture condensation, horizontal transport and deposition of snow, surface and underground runoff, surface and underground inflows, evaporation, changes and moisture reserves in soils and others $[10,11,16]$. The water balance diagram within the city is shown in Fig. 3.1.

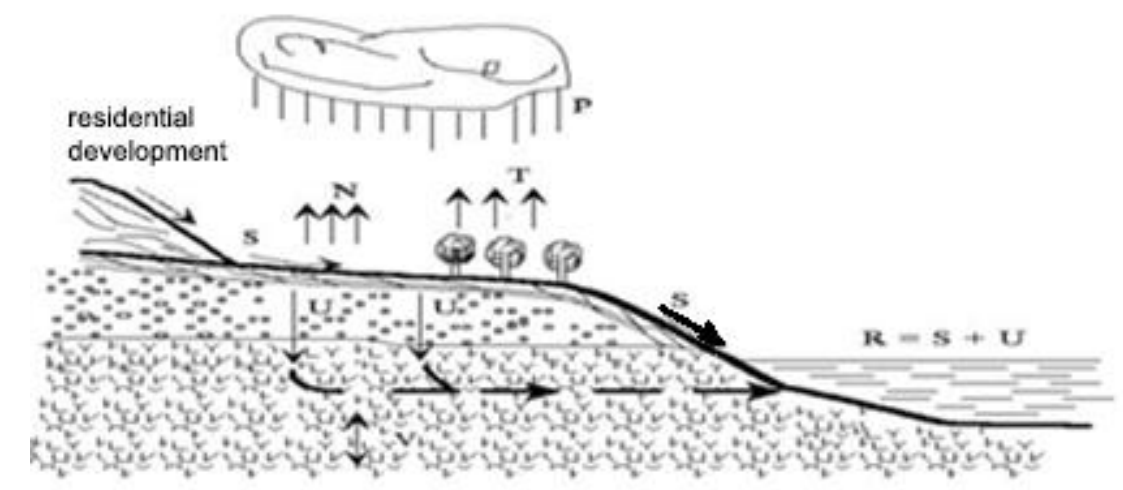

Fig. 4. Landscape water balance diagram.

The calculation of the water balance of the Temernik river and the adjacent landscape within the boundaries of the water protection zone can be performed according to formulas $1,2,3$.

$$
\begin{aligned}
& \mathrm{P}=\mathrm{S}+\mathrm{U}+\mathrm{E}, \\
& \mathrm{W}=\mathrm{U}+\mathrm{E}, \\
& \mathrm{E}=\mathrm{N}+\mathrm{T},
\end{aligned}
$$

where $\mathrm{P}$ - precipitation; $\mathrm{U}$ - underground runoff, $\mathrm{T}$ - transpiration, $\mathrm{W}$ - gross soil moisture, $\mathrm{R}$ - full river flow, $\mathrm{V}$ - water exchange with groundwater, $\mathrm{S}$ - surface runoff, $\mathrm{N}$ evaporation from the soil, $\mathrm{E}$ - total evaporation. In a city, a small river acts as a catchment area in the absence of storm sewers.

Temperature stratification of the $r$. Temernik (temperature change with height in a reservoir) is a leading factor in the placement of organisms in water and affects the transport and dispersion of impurities. This parameter dynamically depends on the season, the section of the river flowing in different functional zones of the city.

In summer, the warmest waters are located at the surface of the water, and the coldest ones at the bottom. In winter, on the contrary, surface cold waters with temperatures lower then $4^{\circ} \mathrm{C}$ are located above warmer waters with temperatures over $4^{\circ} \mathrm{C}$. This movement of water leads to the formation of several temperature layers, between which a layer of temperature jump (thermocline) is formed. Vertical circulation of water allows aquatic organisms to survive in the winter. 
It is known that dissolved oxygen is present in natural water in the form of $\mathrm{O} 2$ molecules. Its content in water is influenced by two groups of oppositely directed processes. The first group of processes enriching water with oxygen includes:

- oxygen absorption process from the atmosphere;

- oxygen release by aquatic vegetation during photosynthesis;

- entering water bodies with rain and snow waters, which are usually oversaturated with oxygen.

Oxygen absorption from the atmosphere occurs on the surface of a water body. The rate of this process increases with decreasing temperature, increasing pressure and decreasing salinity. Aeration - enrichment of deep water layers with oxygen - occurs as a result of mixing of water masses, including wind, vertical temperature circulation, etc.

Photosynthetic oxygen release occurs when carbon dioxide is assimilated by aquatic vegetation (attached, floating plants and phytoplankton). The process of photosynthesis is the stronger, the higher the water temperature, the intensity of sunlight and the more nutrients $(\mathrm{P}, \mathrm{N}$, etc.) in the water. Oxygen production occurs in the surface layer of the reservoir, the depth of which depends on the transparency of the water.

The group of processes that reduce the oxygen content in water includes the reactions of its consumption to the oxidation of organic substances:

- biological (respiration of organisms);

- biochemical (respiration of bacteria, oxygen consumption during the decomposition of organic substances);

- chemical (oxidation $\mathrm{Fe}^{2+}, \mathrm{Mn}^{2+}, \mathrm{NO}_{2-}, \mathrm{NH}_{4}^{+}, \mathrm{CH}_{4}, \mathrm{H}_{2} \mathrm{~S}$ ).

The rate of oxygen consumption increases with increasing temperature, the number of bacteria and other aquatic organisms and substances that undergo chemical and biochemical oxidation. A decrease in the oxygen content in water can be a consequence of its release into the atmosphere from the surface layers, if the water at a given temperature and pressure is supersaturated with oxygen [16-20].

In surface waters, the content of dissolved oxygen varies within a wide range from 0 to $14 \mathrm{mg} / \mathrm{dm}^{3}$ and is subject to seasonal and daily fluctuations. Daily fluctuations depend on the intensity of the processes of its production and consumption and can reach $2.5 \mathrm{mg} / \mathrm{dm}^{3}$ of dissolved oxygen. In winter and summer periods, the oxygen distribution has the character of stratification.

The oxygen concentration determines the magnitude of the redox potential, as well as the direction and rate of the processes of chemical and biochemical oxidation of organic and inorganic compounds. The oxygen regime has a profound effect on the life of the reservoir. The minimum content of dissolved oxygen, ensuring the normal development of fish, is about $5 \mathrm{mg} / \mathrm{dm}^{3}$. Reducing it to $2 \mathrm{mg} / \mathrm{dm}^{3}$ causes mass death of fish. The oversaturation of water with oxygen as a result of photosynthesis processes with insufficiently intensive mixing of water layers also adversely affects the state of the aquatic population.

In accordance with the requirements for the composition and properties of water in reservoirs at points of drinking and sanitary water use, the content of dissolved oxygen in a sample taken before 12 noon should not be lower than $4 \mathrm{mg} / \mathrm{dm}^{3}$ at any time of the year. The oxygen content in the water masses of the river. Temernik, taking into account the degree of pollution, is: $2-3 \mathrm{mg} / \mathrm{dm}^{3}$ in summer, $1-5 \mathrm{mg} / \mathrm{dm}^{3}$ in winter, oxygen saturation $30 \%$ [16-20].

2. Study of anthropogenic impacts on the territory of the water protection zone of the r. Temernik in the study area by study sites and construction of the scheme of pollutant flows (tables 1, 2, 3).

3. Analysis of the river self-cleaning process. 
The ecological state of surface waters largely depends on the self-purification process as a natural restoration of the original properties and composition of water. The main processes of self-cleaning of the river lead to:

- conversion or transformation of pollutants into less toxic ones due to the processes of chemical and biochemical oxidation;

- relative purification due to the transfer of pollutants from the water column to bottom sediments, which can serve as secondary water pollution;

- removal of pollutants beyond the boundaries of a water body as a result of evaporation, release of gases from the water column, wind blowout of foam.

The leading role in the self-purification of waters is played by the process of transformation of pollutants, including non-conservative pollutants, the concentration of which changes as a result of chemical, biochemical and physical processes in water bodies. The intensity of oxidation of the transformed pollutant depends on the properties of this substance, the temperature of the water, and the conditions for the entry of oxygen into the water body [21].

Temperature conditions in the study areas of the river Temernik was assessed by the average temperature for three summer months in the period 2017-2019.

Dynamics of temperatures in summer months for the period 2017-2019 in the study area is shown in Fig. 5. The average water temperature r. Temernik in the study area in the summer period exceeded $20^{\circ} \mathrm{C}[14,15]$.

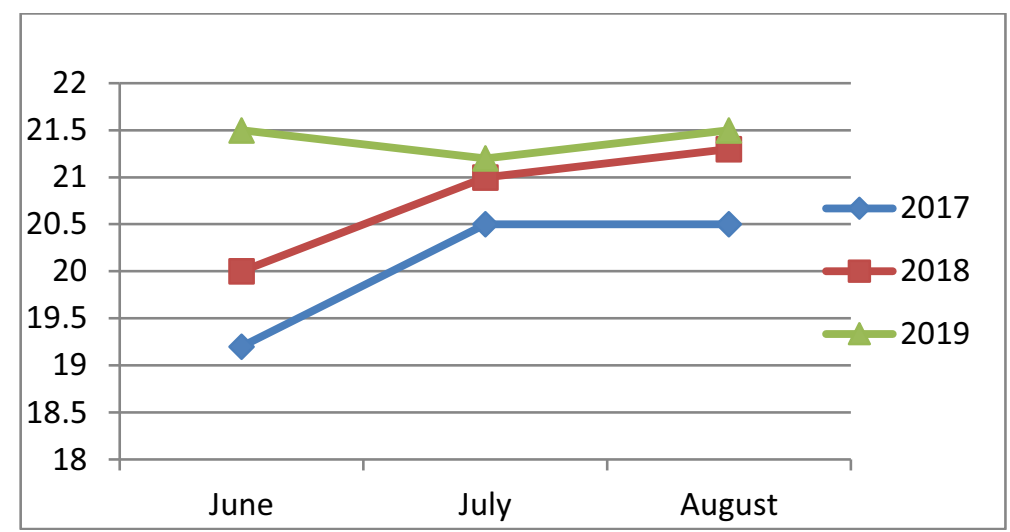

Fig. 5. The graph of the dynamics of temperatures in the summer months for the period 2017-2019 in the study area of the Temernik river.

The conditions for the supply of oxygen to surface waters were estimated by the authors on the basis of the intensity of water mixing, which depends on the nature of the terrain through the shallow water coefficient $(\mathrm{g})$, which depends on the area of the water surface and the average depth of the reservoir.

According to this criterion, the level of mixing in river sections was estimated by the authors as weakly mixed using the example of the section under consideration.

The combination of data from the analysis of the temperature conditions of water masses and the level of their mixing in the river made it possible to classify the processes of self-cleaning of the river, taking place within the boundaries of the studied zone, as unfavorable.

Oxygen deficiency is more often observed in water bodies with high concentrations of polluting organic substances and in eutrophied water bodies containing a large amount of biogenic and humic substances. 
An important role in the self-purification of the river belongs to the process of physical dilution of the content of pollutants, the concentration of which in the water masses decreases with an increase in the flow of water in the river. Due to dilution, the concentration of pollutants decreases, the likelihood of poisoning (toxicosis) of aquatic organisms responsible for the biochemical decomposition of pollutants decreases. As an indicator of the conditions for dilution of pollutants for the river, we used the indicators of the average annual water discharge in the range from less than 100 to more than 10,000 $\mathrm{m}^{3} / \mathrm{s}$. For the Temernik river, this indicator is more than 1000 times.

According to the analysis of two indicators - transformation of pollutants and water consumption, the conditions that develop for self-purification of the Temernik river in the study areas were assessed as extremely unfavorable $[14,15,21,22]$.

4. Construction of a physical model of the process of pollution of a water body

The purpose of constructing a physical model of pollution of a water body, presented in Fig. 6, is to identify consistently dependent processes of formation and transformation of pollutants in the Temernik river basin.



Fig. 6. The process of spreading pollutants in a water body $\left(\mathrm{R}_{\mathrm{sp} 1}\right)$ Physical model of the process of pollution of the water environment of the Temernik river within the city of Rostov-on-Don, where MSW is solid municipal waste [22, 23].

The essence of the physical model of the probability of the process of environmental pollution by waste, taking into account the possible implementation of the corresponding dependent sequential events, can be expressed by the formula:

$$
\mathrm{R}_{\mathrm{P}}=\mathrm{R}_{\mathrm{ob}} \cdot \mathrm{R}_{\mathrm{out}} \cdot \mathrm{R}_{\mathrm{sp}}
$$

where, $\mathrm{R}_{\mathrm{p}}$ - likelihood of water pollution; $\mathrm{R}_{\mathrm{ob}}$ - likelihood of the formation of pollutants; $\mathrm{R}_{\text {out }}$ - likelihood of the release of the resulting pollutants; $\mathrm{R}_{\mathrm{sp}}$ - spread of emitted pollutants.

Formula (4) characterizes the probability of pollution as a set of probabilities of the sequential occurrence of physical processes of the formation and release of pollutants and 
the spread of pollutants in the aquatic environment. It illustrates the interconnected sequence of the individual stages of the transformation of pollutants from their formation to their spread in the aquatic environment. Based on this, a physical model of the process of water body pollution was built.

The diagram of the physical model of the probability of the process of pollution of a water body is shown in Fig. 6.

5. Physical model of the process of reducing pollution of a water body.

Based on the analysis of the physical model of water pollution, we have developed a physical model of the process of reducing water pollution in the river Temernik, shown in Fig. 7, including the parameters of the water protection zone, the organization of MSW collection, shore protection works, the parameters of landscaping and landscaping, the expansion and deepening of the channel, the parameters of the recreational zone $[3,7,8$, 23-25].



Fig. 7. Physical model of the process of reducing pollution of the aquatic environment.

The development of an algorithm for the ecological rehabilitation of the river. Temernik is the previously analyzed comprehensive assessment of the design area in Table 4. 
Table 4. Comprehensive assessment of the territory in the design area [9, 13-15].

\begin{tabular}{|c|c|c|}
\hline Criteria group & Criterion value intervals & $\begin{array}{l}\text { Analysis of criteria in terms } \\
\text { of creating a continuous } \\
\text { landscape park }\end{array}$ \\
\hline 1 & 2 & 3 \\
\hline \multicolumn{3}{|c|}{ climatic } \\
\hline climate type & moderate continental & satisfies \\
\hline air temperature & $\begin{array}{l}\text { The coldest month is January with an average } \\
\text { temperature }-3,0^{\circ} \mathrm{C} \text {. } \\
\text { The warmest month is July, its average daily } \\
\text { temperature }+23,4^{\circ} \mathrm{C} \text {. }\end{array}$ & satisfies \\
\hline average annual precipitation, $\mathrm{mm}$ & 618 & satisfies \\
\hline air humidity, $\%$ & 72 & satisfies \\
\hline average wind speed, $\mathrm{m} / \mathrm{s}$ & 3,2 & satisfies \\
\hline \multicolumn{3}{|c|}{ landscape-topographic } \\
\hline section length, $\mathrm{km}$ & 3,56 & satisfies \\
\hline relief & average slope $2-3 \%$ & satisfies \\
\hline landscape type & urban landscape with elements of valley-river & satisfies \\
\hline land cover & has a zonal character & satisfies \\
\hline economic use of the territory & functional areas & satisfies \\
\hline soil types & natural-alluvial, anthropogenically transformed & satisfies \\
\hline $\begin{array}{l}\text { the degree of disturbance of the natural } \\
\text { landscape }\end{array}$ & $50 \%$ & satisfies \\
\hline $\begin{array}{l}\text { types of vegetation of the water protection } \\
\text { zone }\end{array}$ & $\begin{array}{l}\text { arboreal and shrubby in the water protection } \\
\text { zone, aquatic in the coastal strip }\end{array}$ & satisfies \\
\hline $\begin{array}{l}\text { landscape aesthetics } \\
\text { scenery: } \\
\text { viewpoints } \\
\end{array}$ & sector and panoramic viewpoints & $\begin{array}{c}\text { satisfies } \\
\text { depth of landscape } \\
\text { perspective } 200-400 \mathrm{~m}\end{array}$ \\
\hline cultural landscape & weakly expressed & \\
\hline \multicolumn{3}{|c|}{ hydrological } \\
\hline groundwater level, $\mathrm{m}$ & lower then 1 & satisfies \\
\hline water chemistry & hydrocarbonate-sulphate & not satisfies \\
\hline river bed width, $\mathrm{m}$ & 2 to 10 & not satisfies \\
\hline river bed depth, $\mathrm{m}$ & $0,3-2$ & not satisfies \\
\hline silt layer height, $\mathrm{m}$ & $0,5-3$ & not satisfies \\
\hline average water temperature in summer, ${ }^{\circ} \mathrm{C}$ & 21 & satisfies \\
\hline oxygen content in water, $\mathrm{mg} / \mathrm{dm}^{3}$ & $\begin{array}{l}\text { in summer 2-3, } \\
\text { in winter } 1-5\end{array}$ & $\begin{array}{c}\text { not satisfies } \\
\text { oxygen saturation } 30 \% .\end{array}$ \\
\hline mixing level of water masses & weak, middle & not satisfies \\
\hline \multicolumn{3}{|c|}{ urban planning } \\
\hline types of economic activities & & not satisfies \\
\hline remoteness from residential buildings & $25-50 \mathrm{~m}$ from private buildings & satisfies \\
\hline distance from roads & 2 road bridges across the river & not satisfies \\
\hline sealed territory & $40-50 \%$ & not satisfies \\
\hline degree of landscaping & $50-70 \%$ & not satisfies \\
\hline aesthetic value of the landscape & potentially high & satisfies \\
\hline \multicolumn{3}{|l|}{ ecological } \\
\hline width of the sanitary protection zone & 100 & satisfies \\
\hline air pollution index for 5 substances IPA 5 & 7 & moderate, satisfies \\
\hline air pollution index IPA & $2,0-4,0$ & $\begin{array}{c}\text { not satisfies, } \\
\text { water quality class } 4, \\
\text { polluted }\end{array}$ \\
\hline Potential for air pollution PPA & zone II & $\begin{array}{c}\text { not satisfies, } \\
\text { zone of high pollution }\end{array}$ \\
\hline $\begin{array}{l}\text { Total indicator of the chemical } \\
\text { contamination of the soil, Zs s }\end{array}$ & $1,3-4,4$ & $\begin{array}{l}\text { satisfies, } \\
\text { less than } 16 \\
\text { permissible }\end{array}$ \\
\hline $\begin{array}{c}\text { Total indicator of chemical pollution of } \\
\text { bottom sediments } \\
\text { Zs b }\end{array}$ & $30-100$ & $\begin{array}{c}\text { not satisfies, } \\
\text { many times higher than the } \\
\text { background, stable excess } \\
\text { of individual elements of } \\
\text { MPC levels }\end{array}$ \\
\hline Water quality class & $\mathrm{V}$ & not satisfies, dirty \\
\hline $\begin{array}{c}\text { average equivalent noise level: } \\
\text { in the daytime } \\
\text { at night }\end{array}$ & $\begin{array}{l}60 \mathrm{~dB} \\
45 \mathrm{~dB}\end{array}$ & $\begin{array}{c}\text { satisfies, } \\
\text { exceeding the permissible } \\
\text { level in the daytime }\end{array}$ \\
\hline the degree of littering of the coastal strip & $8-10 \%$ territory & $\begin{array}{l}\text { not satisfies, } \\
\text { spontaneous MSW in the } \\
\text { coastline zone }\end{array}$ \\
\hline
\end{tabular}


The low quality of water in the river Temernik is facilitated by uncontrolled discharges of storm and waste water, the total inflow of which during the low-water period is estimated at $60-80 \mathrm{l} / \mathrm{s}$, and with intense rainfall at $11-12 \mathrm{~m}^{3} / \mathrm{s}$, which leads to discharge into the river, only from these sources, up to 500 tons of sediment from the territory of urban development, the main part of which settles in the channel.

A silted, overgrown, littered channel has a low carrying capacity, which leads to periodic flooding of adjacent territories, households of citizens during the period of intense rainfall, additionally washing away a large amount of sediment and debris from the flooded territory into the river $[14,15,22]$.

\section{Conclusions}

For this purpose, a factor-by-factor ecological analysis of the design area was carried out; the processes of the main intake of pollutants into the water protection zone and the river bed were identified. With the help of the constructed physical model of the process of reducing soil pollution in the water protection zone, a technology of bank-strengthening structures and a project of landscaping and landscaping of the territory within the boundaries of the projected linear ecological park along the Temernik river have been developed.

As a result of the study of the natural complex, the features were revealed and the following principles for the formation of the ecological frame were proposed:

- formation of the backbone of the ecological framework of the territory of the Rostov region (cores and corridors) due to the elements of the girder-channel network;

- development of a system of specially protected natural areas (PAs) and areas of limited nature use by increasing the territories included in the "forest park green belt";

- formation of a holistic and continuous ecological framework of the city, including the territories of various regimes of regulated nature management;

- ensuring the conditions for creating a buffer zone of the ecological framework, based on the polarized landscape model;

- creating conditions for protecting the landscape attractiveness of natural complexes, increasing the landscape identity of the Don landscapes;

- formation of agro-belts of natural-like farming around settlements.

The boundaries of the territories on which the formation of a forest-park belt is planned are determined based on the characteristics of the landscape and the prospects for the development of the Big Rostov agglomeration.

The current ecological state of the design zone is assessed as unsatisfactory in terms of the sanitary state of the existing frame landscaping, represented by old-growth plantings of common poplar, seemingly three-prickled, common elm, common willows that have now lost their aesthetic appeal and poses a threat to vacationers due to shrinking trunks.

Stages of work:

1. Inventory of the existing fund of perennial plantings in accordance with the act of inspection of green spaces dated 09/18/2017.

2. Design of a transit zone, represented by pedestrian and bicycle paths.

3. Allocation of quiet recreation areas and a dock area for pleasure boats.

4. Development of a landscape gardening scheme with perennial trees and shrubs.

\section{References}

1. Zheng, Zihao, et al., Ecological Indicators, 119 (2020)

2. Yi, Sangchoul, S. Kim, Ocean\&Coastal Management, 195 (2020) 
3. G. Halkos, S. Matsiori, Economic Analysis and Policy, 58, 153-166 (2018)

4. M. Ruckelshaus, et al., International Journal of Disaster Risk Reduction, 51 (2020)

5. F. Leone, Z. Corrado, Sustainability, 11 (18) (2019)

6. N. V., Ivanova, O. A. Ganzha, and V. V. Prokopenko, IOP Conf. Ser.: Mater. Sci. Eng., 463, 2 (2018)

7. M. M. Mahmudi, L. Eslami, Urban Management, 9 (28), 81-92 (2012)

8. S. Liang, W. Jiang, a J. Sun, In Proceedings of the 28th International Ocean and Polar Engineering Conference, International Society of Offshore and Polar Engineers, 10 June 2018 (2018)

9. E. Bingöl, A|Z ITU Journal of Faculty of Architecture, 17(2), 159-170 (2020)

10. S. Guo, S. Wang, L. Chen, Journal of Coastal Research, 108 (SI), 221-225 (2020)

11. Z. I. Gaivoronskaya, G. N. Aidarova, Bulletin of Kazan State University of Architecture and Civil Engineering, 4 (42) (2017)

12. L. I. Karimova, E. V. Denisenko, Bulletin of Kazan State University of Architecture and Civil Engineering, 1 (47) (2019)

13. Sh.Perkol-Finkel, et al., Ecological Engineering, 120, 645-654 (2018)

14. Ecological Bulletin of Don. Report "On the State of the Environment and Natural Resources of the Rostov Region in 2018" (2018), URL: https://docviewer.yandex.ru/view/0/?page $=2 \& *$

15. The concept of the project "Rehabilitation of the River Temernik with the arrangement of the coastal strip in the citywide Ecological Park" (2016, 2019), URL: http://parktemernik.ru/index.php/about-2

16. P. R. Kannel, et al., Environmental Modeling \& Assessment, 16 (2), 183-204 (2011)

17. N. Sinan, B. Mete, and A. Bayram, Environmental Monitoring and Assessment, 192 (12), 1-21 (2020)

18. A. Csábrági, et al., Ecological Engineering, 138, 298-309 (2019)

19. A. Rajwa-Kuligiewicz, R. J. Bialik, and P. M. Rowiński, Journal of Hydrology and Hydromechanics 63 (4), 353-363 (2015)

20. H. Haider, W. Ali, and S. Haydar. Pakistan Journal of Engineering and Applied Sciences (2016)

21. M. R. Salla, et al., Journal of Urban and Environmental Engineering, 8 (1), 118-133 (2014)

22. Ye. S. Kabiyev, et al., GeoJournal of Tourism and Geosites, 11 (3), 644-655 (2018)

23. Zh. G. Berdenov, et al., Geojournal of Tourism and Geosites, 18 (2), 187-195 (2016)

24. R. Bhandari, Riverbank Protection with Gabion Structure: Gabion Mattress (2019)

25. S. Guan-Chyun, and T. Cheng-Yung, In Proceedings of International Conference on Materials for Renewable Energy \& Environment, 2. IEEE (2011) 